\title{
Życie osoby z częściową głuchotą przed wszczepieniem i po wszczepieniu implantu ślimakowego - studium przypadku
}

\section{Life experience of a patient before and after partial deafness treatment (PDT) - case study}

\section{Anna Obszańska}

Instytut Fizjologii i Patologii Słuchu, Światowe Centrum Słuchu, Zakład Implantów i Percepcji Słuchowej, Warszawa/Kajetany

Adres autora: Anna Obszańska, Światowe Centrum Słuchu, Zakład Implantów i Percepcji Słuchowej, ul. Mokra 17, Kajetany, 05-830 Nadarzyn, e-mail: a.obszanska@ifps.org.pl

\section{Streszczenie}

Wstęp: Częściowa głuchota jest rodzajem utraty słuchu w zakresie częstotliwości wysokich, przy prawidłowej lub ograniczonej percepcji dla tonów niskich. Pacjenci z częściową głuchotą objęci są Programem Leczenia Częściowej Głuchoty z użyciem implantu ślimakowego.

Cel: Celem pracy jest przedstawienie zmian, które zaszły w życiu osoby z częściową głuchotą przed wszczepieniem implantu i po jego wszczepieniu w świetle konsekwencji niepełnosprawności, w odniesieniu do trzech modeli niepełnosprawności: medycznego, funkcjonalnego i społecznego.

Material i metody: W celu realizacji tego zadania wykorzystano badania jakościowe przy użyciu metody studium przypadku z zastosowaniem wywiadu pogłębionego.

Wyniki: Z przeanalizowanego wywiadu udało się wyodrębnić zmiany, które zaszły w życiu osoby z częściową głuchotą przed wszczepieniem i po wszczepieniu implantu, a następnie zinterpretować je w odniesieniu do trzech modeli: medycznego, funkcjonalnego i społecznego.

Wnioski: Życie pacjentki po wszczepieniu implantu ślimakowego zmieniło się dzięki zmniejszeniu się konsekwencji niepełnosprawności w obszarze implikacji biologicznych, psychicznych i społecznych. Nie stwierdzono zmian odnośnie przeobrażenia nastawienia społecznego względem osoby niepełnosprawnej.

Słowa kluczowe: częściowa głuchota • niepełnosprawność • implant ślimakowy • konsekwencje niepełnosprawności • medyczny model niepełnosprawności • funkcjonalny model niepełnosprawności • społeczny model niepełnosprawności

\section{Abstract}

Background: Partial deafness is a type of hearing loss in a high frequency range with normal or reduced perception of low tones. Patients with partial deafness are covered by the Program of Partial Deafness Treatment (PDT) using cochlear implants.

Aim of the study: The aim of the study is to present the changes that took place in the life of an individual with partial deafness in terms of effects of disability before and after implantation, based on three disability models: medical, functional and social.

Material and methods: This task has been accomplished through qualitative methods using case study approach with the indepth interview.

Results: Interview has been analyzed from the point of view of disability effects using three models of disability.

Conclusions: Patient's functioning after cochlear implantation has changed, as the effects of disability have been mitigated in the areas of its biological, psychological and social implications. No changes were observed in relation to the change of the attitude of the society towards the disabled person. 
Key words: partial deafness $\bullet$ disability $\bullet$ cochlear implant $\bullet$ disability effects $\bullet$ medical model of disability $\bullet$ functional model of disability • social model of disability

\section{Wstęp}

\section{Częściowa głuchota}

Pacjenci, u których stwierdzono głęboki, wysokoczęstotliwościowy niedosłuch przy jednocześnie obniżonej lub występującej w normie czułości słuchu dla niskich częstotliwości, jeszcze do niedawna pozostawali poza możliwościami skutecznej pomocy. Ta grupa pacjentów, pomimo coraz większej skuteczności nowoczesnych rozwiązań technologicznych, nie uzyskuje satysfakcjonujących wyników ze stosowania klasycznych aparatów słuchowych nowej generacji. Ten rodzaj ubytku słuchu został określony przez Skarżyńskiego mianem „częściowa głuchota” [1]. Pacjenci z częściową głuchotą nie byli przez długi czas kwalifikowani do wszczepienia implantu ślimakowego, ponieważ istniała obawa, że podczas operacji zniszczony zostanie sprawnie funkcjonujący fragment ucha wewnętrznego. W 2002 roku Skarżyński przeprowadził pierwszą w świecie operację wszczepienia implantu ślimakowego u pacjentki z częściową głuchotą i rozpoczął wraz ze współpracownikami Program Leczenia Częściowej Głuchoty (ang. Partial Deafness Treatment, PDT) [1-8]. Zachowanie słuchu dla niskich częstotliwości pozwoliło na wdrożenie nowatorskiej koncepcji połączenia w tym samym uchu częściowo funkcjonującego słuchu akustycznego z nowym słuchem elektrycznym [9]. Koncepcja ta polega na elektrycznej stymulacji uszkodzonej części receptora słuchowego za pośrednictwem systemu implantu ślimakowego oraz jednoczesnym pobudzeniu akustycznym jego funkcjonującej części w zakresie niskich częstotliwości [9]. Założono, że zastosowanie stymulacji elektrycznej za pośrednictwem implantu ślimakowego, przywracającej słyszenie wysokich częstotliwości, przy zachowaniu słuchu pacjenta dla niskich częstotliwości, jest sposobem na uzyskanie znacznej poprawy dyskryminacji mowy [1-3].

Częściowa głuchota jest rodzajem uszkodzenia narządu słuchu, a zatem prowadzi do niepełnosprawności sensorycznej [10]. Definicji niepełnosprawności jest wiele, w zależności od kwestii interesującej badacza. Są definicje ogólne i szczegółowe, które uzupełniają się wzajemnie [11]. Niepełnosprawność to wielowymiarowe zjawisko [12]. Posiłkując się definicją zawartą w ustawie o pomocy społecznej z dnia 29 listopada 1990 roku, można stwierdzić, że niepełnosprawność oznacza stan fizyczny, psychiczny lub umysłowy powodujący trwałe lub okresowe utrudnienie, ograniczenie bądź uniemożliwienie egzystencji [11]. Utrudnienia i ograniczenia te wynikają z różnych aspektów niepełnosprawności, począwszy od ściśle biologicznych po społeczne. Korespondują zatem z trzema modelami niepełnosprawności: biomedycznym (medycznym), funkcjonalnym (interakcyjnym) i społecznym (socjopolitycznym) [13].

\section{Modele niepełnosprawności}

Model medyczny niepełnosprawności określa niepełnosprawność w kategoriach uszkodzenia, dysfunkcji ciała, które utrudnia funkcjonowanie człowieka i które można wyleczyć lub zminimalizować poprzez interwencję specjalisty. Pacjent jest zatem przedmiotem oddziaływań medycznych, któremu należy się wsparcie społeczne [13]. Konsekwencją niepełnosprawności będzie więc stopień uszkodzenia oraz dysfunkcji danego narządu lub układu narządów. W przypadku niepełnosprawności słuchowej uszkodzony jest układ słuchowy i zaburzona jest jego funkcja, którą jest percepcja słuchowa. Mamy zatem do czynienia $\mathrm{z}$ konsekwencjami biologicznymi.

Z kolei model funkcjonalny niepełnosprawności bierze pod uwagę wiele czynników i zakłada podejście holistyczne wobec pacjenta, $z$ uwzględnieniem jego sfery fizycznej, osobistej, społecznej. Zatem pogarszający się stan zdrowia może się przekładać na ograniczenie funkcjonowania fizycznego (przykładowo niesprawność motoryczna i somatyczna), psychicznego (sensoryczna i umysłowa), jak i społecznego (niesprawność w realizacji zachowań związanych z przyjętymi normami społecznymi).

W przypadku niepełnosprawności słuchowej (takiej jak np. częściowa głuchota) konsekwencjami uszkodzonego układu słuchowego będą zatem ograniczenia funkcjonalne głównie w obszarze aktywności psychicznej (ograniczenie słyszenia i interpretacji informacji sensorycznej) oraz aktywności społecznej (wypełnianie ról społecznych) [13].

Natomiast model społeczny sprowadza kwestię niepełnosprawności do barier, które istnieją poza jednostką niepełnosprawną, i uprzedzeń społecznych [13]. Model ten uwzględnia utratę czy zmniejszenie funkcjonalności człowieka, ale głównie akcentuje możliwość i potrzebę modyfikacji społeczeństwa, by pomóc osobie niepełnosprawnej - poprzez usunięcie barier - $\mathrm{w}$ realizacji siebie [14]. $\mathrm{W}$ tak rozumianym modelu konsekwencją niepełnosprawności w odniesieniu do zmysłu słuchu będzie wykluczenie społeczne spowodowane stosunkiem społeczeństwa i wszelkimi działaniami, bądź ich brakiem, utrudniającymi uczestnictwo w życiu społecznym. Konsekwencją niepełnosprawności będzie rodzaj opresji, niezrozumienia czy utrudnienia społecznego.

\section{Cel pracy}

Celem niniejszej pracy jest ukazanie zmian, które zaszły w życiu osoby z częściową głuchotą w świetle konsekwencji niepełnosprawności przed wszczepieniem i po wszczepieniu implantu, aby podjąć próbę dostrzeżenia obszarów mogących być przedmiotem dalszych badań.

\section{Materiał i metody}

W pracy posłużono się metodą studium przypadku z zastosowaniem metodologii badań jakościowych. Metoda ta może być wstępem do głębszej analizy naukowej podjętego zagadnienia przy użyciu - w dalszej perspektywie - badań ilościowych.

W przeprowadzonym badaniu zastosowano wywiad pogłębiony, indywidualny, w trakcie którego badacz prosi 

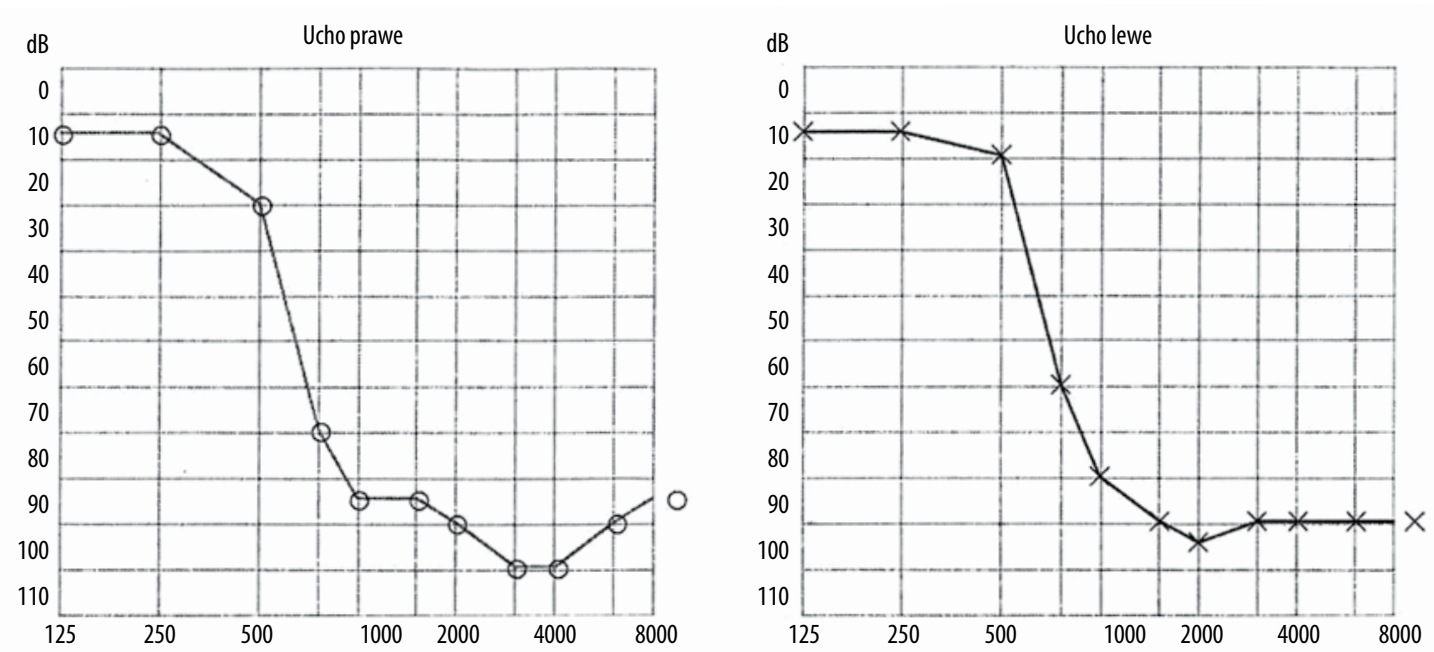

Rycina 1. Przedoperacyjny wynik audiometrii tonalnej [1] kwalifikujący pacjentkę z częściową głuchotą do grupy EC (elektryczna komplementacja) wg klasyfikacji Skarżyńskiego [6]

Figure 1. Preoperative pure tone audiometry [1] results indicating the PDT-EC (Partial Deafness Treatment - electric complementation) group according to the Skarzynski PDT Classification [6]

badaną osobę, aby opowiedziała o danym problemie lub fragmencie swojego życia [15]. Gwarancją wiarygodności danych jest tutaj bezpośredniość kontaktu z badanym [16]. Jest to forma dialogu, w oparciu o empatię, umiejętność słuchania, zaufanie i chęć wzajemnego komunikowania się. W dialogu tym istotne jest stworzenie poczucia bezpieczeństwa [15].

W omawianym przypadku zastosowano wywiad nieskategoryzowany (niewystandaryzowany), a zatem niezawierający gotowego kwestionariusza pytań zamkniętych, oparty na swobodnej wymianie zdań. Wykorzystano gotową listę pytań zamkniętych i otwartych (zmieniano treść, kolejność pytań, uzupełniając o interesujące wątki), pozostawiono zatem dużą swobodę i miejsce na inwencję własną zarówno badającemu, jak i osobie uczestniczącej w wywiadzie. Wywiad miał charakter jawny ze względu na sformułowanie celu badania i poinformowanie o nim osoby badanej [16].

\section{Opis przypadku}

Trzydziestokilkuletnia kobieta, z obustronną częściową głuchotą, użytkowniczka dwóch implantów ślimakowych (w uchu lewym od 2003 roku, w uchu prawym od 2009 roku). Niedosłuch o etiologii idiopatycznej zdiagnozowany został $\mathrm{w}$ wieku 14 lat. Badania molekularne w kierunku wybranych mutacji nie potwierdziły pochodzenia genetycznego. Wynik badania audiometrycznego przeprowadzonego przed operacjami wszczepienia implantów ślimakowych zamieszczono na rycinie 1. Próg słyszenia zmierzony w polu swobodnym w warunkach odsłuchowych przez dwa systemy implantów ślimakowych zawierał się w przedziale od 20 do $30 \mathrm{~dB}$ w szerokim zakresie częstotliwości (zakres badanych częstotliwości - od $250 \mathrm{~Hz}$ do $6000 \mathrm{~Hz}$ ). Wynik badania dyskryminacji słów jednosylabowych wyniósł odpowiednio 100\% i 90\% dyskryminacji w ciszy i w szumie (stosunek szumu do sygnału - $\mathrm{SNR}=10 \mathrm{~dB}$ ) $[17,18]$. Pacjentka charakteryzuje się wysokimi kompetencjami językowymi, posiada ponadprzeciętny zasób słownictwa, posługuje się mową niezwykle sprawnie i potrafi zajmująco opowiedzieć o wszystkim co jest reprezentacją jej świata pojęć i umiejętności komunikacyjnych. Pacjentka jest osobą pracującą, zakończyła edukację na poziomie wyższym, jest aktywna zawodowo i społecznie.

\section{Wyniki}

\section{Wywiad}

Wywiad został przeprowadzony na terenie Światowego Centrum Stuchu w Kajetanach, odbyt się na zasadzie osobistej rozmowy oraz wymiany korespondencji e-mailowej. Niektóre wypowiedzi sa przytaczane i cytowane wprost, niektóre sa relacjonowane przez autora tekstu. Ze względu na anonimowy charakter wywiadu imię uczestniczki wywiadu nie zostało podane.

Witam,

chciałabym z Panią porozmawiać o niedosłuchu, o tym, jak wyglądało Pani życie przed wszczepieniem i po wszczepieniu implantu. $Z$ tego, co się orientuję, pierwsza operacja miała miejsce w trakcie studiów. Dlatego bardzo interesuje mnie, jak Pani sobie radziła we wcześniejszych latach szkolnych i jak wyglądało Pani późniejsze życie. Co przyczyniło się do podjęcia decyzji o operacji wszczepienia implantu ślimakowego, najpierw do jednego, a następnie do drugiego ucha? Jakie były Pani obawy, nastawienie, oczekiwania, jakie emocje towarzyszyły Pani, co było najtrudniejsze, a co było pomocne, jakie były z tym związane nadzieje co do przyszłości?...

Oczywiście, jeśli wolałaby Pani nie poruszać jakiegoś zagadnienia, jest to zrozumiałe, proszę o to, by udzielała Pani odpowiedzi w takim zakresie, na ile chce Pani rozwinąć dany wątek. Proszę nie czuć żadnej presji z tego tytułu. Pytania mają charakter anonimowy i będą wykorzystane jedynie w celach naukowych, by wzbogacić wiedzę na temat pacjentów z problemem niedosłuchu oraz trudności i wyzwań, przed którymi oni stają. Będę Pani zadawać 
pytania, jeśli jednak będzie Pani chciała zmienić kierunek rozmowy bądź poruszyć inną kwestię, jest to z mojej strony mile widziane.

\section{Kiedy Pani zdała sobie sprawę, że „coś jest nie tak”} z Pani słuchem?

Trudno wskazać taki właściwy moment uświadomienia sobie samej, od kiedy źle słyszę. Na początku informacja przyszła z zewnątrz. Ktoś to zdiagnozował. Moja świadomość zaczęła się kształtować później, kiedy zaczęłam obserwować sytuacje i doszłam do wniosku, że nie odbieram pewnych sytuacji tak jak osoba słysząca.

\section{Czy mogłaby Pani powiedzieć coś więcej na ten temat?}

Gdy miałam ok. 14 lat, usłyszałam, że nie mam normy słuchowej. Stało się tak po badaniu na przenośnym audiometrze, w warunkach nie do końca przystosowanych do takiego pomiaru. Dostałam skierowanie na powtórzenie badań. Było to parokrotnie weryfikowane badaniami w szpitalach, w kabinach ciszy. Niestety, potwierdziło się. Wtedy wychwycono mój niedosłuch. Ale gdy dziś zastanowię się nad przeszłością, wiedząc to, co wiem teraz i rozumiem na temat niedosłuchu, problem można było wychwycić wcześniej - około 12 roku życia. Tylko to było trudne zadanie. Nikt $\mathrm{z}$ bliskiego otoczenia - rodzice, nauczyciele - nie zauważył, że czegoś mi brakuje lub że się nieadekwatnie zachowuję. Radziłam sobie. Może dlatego, że niedosłuch nie nastąpił nagle, ale pogłębiał się bardzo małymi kroczkami. Nie było to kontrastowe. Nie wybijało się. Ja sama nie zauważyłam. Ale nie mam o to do siebie pretensji. Byłam dzieckiem. Do dorosłych też nie mam. Brakowało im wiedzy i doświadczenia. Nie byli przecież muzykami, lekarzami, logopedami, czyli osobami o wyostrzonym postrzeganiu bodźców dźwiękowych.

Ciekawe jest też to, że wykrycie mojej wady to jedno, ale nie było to łatwe do leczenia, do aparatowania. Wszelkie próby aparatowania kończyły się niepowodzeniem. Nawet po kolejnych latach prób, gdy wchodziły coraz lepsze aparaty cyfrowe. Za każdym razem aparaty wzmacniały to, co dobrze słyszałam - było to nienaturalnie za głośno. Nie wspomagały natomiast tego, czego nie słyszałam. Okropne uczucie.

\section{Co było najtrudniejszego w tym okresie?}

Chyba taka niejasność, nieostrość rozumienia własnej sytuacji. Nie myślałam, że mam kłopot ze słuchem tylko z innymi sferami. Myślałam, że nie wyrabiam się jak inni, jestem powolna, „gapowata”, za bardzo zamyślona. Gdy zaczęłam łączyć to, co się dzieje, $\mathrm{z}$ niedosłuchem, to musiałam też siebie definiować na nowo - to, jaka jestem.

\section{Kiedy wspomina Pani czasy szkolne i licealne, jak po- strzega Pani siebie?}

Byłam niepewna siebie, spięta, nie mogłam się dobrze odnaleźć w grupie. Ciągle coś uzupełniałam, robiłam notatki, więcej czytałam, żeby być na tym samym poziomie informacji co rówieśnicy.
Jak niedosłuch wpływał na Panią, na Pani bliskich czy inne osoby $z$ otoczenia?

Na moich bliskich raczej nie widziałam, żeby jakoś wpływał. Radziłam sobie sama. Czy moim rówieśnikom dokuczało to, że nie słyszę pewnych dźwięków? Chyba też nie. Mogło to bardziej wpływać na ich postrzeganie mojej osoby, np. wołają mnie, a ja nie reaguję albo odpowiadam nie na temat.

Jak wyglądały Pani relacje $z$ rówieśnikami, nauczycielami, jak oni Panią traktowali, wiedząc lub nie wiedząc o Pani niedosłuchu?

Raczej nikt nie wiedział, że mam niedosłuch. Po części dlatego, że ja sama dobrze nie zdawałam sobie z tego sprawy. Nauczyciele nie zauważali, iż coś ze mną się dzieje. Byłam jednym z wielu uczniów. Osiągałam wyniki w nauce nieodbiegające od średniej. Raz wypadałam bardzo dobrze, raz średnio. Nic, co niepokoi. Z rówieśnikami miałam dobre relacje. Ale pamiętam, że trudno mi było rozmawiać w gwarze, nie wdawałam się w grupowe dyskusje na przerwie, nie łapałam żartów klasowych. Zawsze gdy na lekcjach były dyskusje lub ktoś wypowiadał się, odwracałam się, by lepiej wychwycić, co mówi. Raczej nawiązywałam wiele indywidualnych kontaktów, jeden na jeden.

\section{W jaki sposób radziła Pani sobie $\mathrm{z}$ tą sytuacją?}

Miałam czasem wrażenie, że jestem w niektórych momentach postrzegana jako gapa albo „z uśmiechem”. Ale miałam poczucie własnej wartości. Starałam się tym nie przejmować.

Co, lub może kto, miało decydujący wpływ na podjęcie przez Panią decyzji o wszczepieniu pierwszego implantu ślimakowego?

Trudno wskazać mi taką osobę lub jedno zdarzenie. To był splot wielu zdarzeń, spotkanie wielu osób. Myślę, że zaszedł we mnie pewien proces. Gdy rozpoczęła się diagnostyka w kierunku implantu, zaczęłam otrzymywać informacje. Mogłam porozmawiać z lekarzami, którzy rozumieli moją sytuację i moje problemy. Pierwszy raz poczułam się zrozumiana. Diagnostykę w kierunku implantu przeszłam dwukrotnie. Podczas drugiej diagnostyki rozmawiałam $\mathrm{z}$ osobą, która miała implant od ok. 3-4 miesięcy. Zadałam jej wiele pytań. I doszło do mnie po tej rozmowie, że choć używa go krótko, to już docierają do niej dźwięki, które dla mnie umarły. To było bardzo motywujące. Próbowałam nosić aparaty słuchowe, ale one nic nie wzmacniały, nie słyszałam w nich utraconych dźwięków.

Jakie były Pani obawy, lęki, wyobrażenia, nadzieje związane $z$ operacją?

To miała być moja pierwsza w życiu operacja. Dziwnie się z tym czułam. Nigdy nie przeżyłam ingerencji chirurgicznej. Nigdy nie byłam pod narkozą. To naturalne, że człowiek trochę się obawia. Na pewno myślałam: Czy wszystko się uda? Czy operacja przebiegnie bez powikłań. Myślałam o tym, ale też o okresie po operacji. Zastanawiałam się, jak będę słyszeć? Doszłam jednak do wniosku, że nawet jeśli będzie to słyszenie metaliczne, to trudno... 
bo będę słyszeć coś więcej... a ja już byłam bardzo zmęczona ciągłym nadrabianiem różnymi sposobami w sytuacjach, kiedy coś mi uciekało lub mogło uciec. Musiałam ciągle przewidywać.

Pierwsze chwile po wszczepieniu implantu wspomina Pani jako...

Zaskakujące. Można sobie coś wyobrażać, ale kiedy się zacznie rzeczywiście czegoś doświadczać, to nagle dochodzi do zderzenia tych wyobrażeń z rzeczywistością.

Jakie były Pani pierwsze przeżycia, doznania, co najsilniej utkwiło Pani w pamięci po podłączeniu procesora?

Zaskoczyło mnie, że jest inaczej niż w aparacie słuchowym, że mimo iż nie słyszę jeszcze dobrze, to akceptuję to, co do mnie dochodzi, że cisza jest taka wyraźna, nawet głośna, że są dźwięki, o których nie miałam pojęcia, bo ich nigdy nie słyszałam, a teraz dochodzą do mnie. Urodziłam się słysząca i miałam pamięć dźwiękową, ale nigdy nie słyszałam np. dzwonka telefonu komórkowego. Znałam tylko dźwięk telefonu stacjonarnego. Widziałam nowe technologie, ale nie słyszałam ich dźwięków.

\section{Co pomogło w tym okresie „nauki dźwięków”?}

Chyba to, że podchodziłam badawczo do sytuacji. Były momenty, że czułam się zdezorientowana, zaskoczona, zakłopotana, poirytowana, ale próbowałam skupiać się nie na tym, co mi sprawia trudność, ale co w ogóle do mnie dochodzi, otaczałam się dźwiękami i poddawałam ich stymulacji. Gdy było trudno, nigdy nie zdjęłam procesora, trwałam przy tym, by się osłuchać.

\section{Kiedy Pani świat zaczął nabierać „barw”?}

Zależy, jak na to spojrzeć. Można z dwóch punktów. Jeden to: od początku, kiedy dzień po dniu malutkimi kroczkami, bezkształtnie, ale już coś, dochodziło do mnie, czego wcześniej nie było. Drugi punkt widzenia: to po około roku, kiedy zrozumiałam, że zaczyna się dla mnie stopniowo stabilizować słyszenie i rozumienie. Odczuwałam, że mogę coraz bardziej zaufać nowemu słyszeniu, poczuć się pewniej.

\section{Co było największym zaskoczeniem?}

Wiele dźwięków i sytuacji. Jednak dużą radość sprawiła mi muzyka i doznania $z$ nią związane.

Jaki wpływ miała operacja wszczepienia implantu na Pani dalsze życie? Co się zmieniło?

Znów chyba bardziej we mnie niż w innych. Zaczęłam rozumieć, czym jest mój niedosłuch, miałam już porównanie na bieżąco - równolegle, co to znaczy nie słyszeć i słyszeć. Nauczyłam się mówić o niedosłuchu w sposób otwarty. Wzrosła moja samoświadomość. Przez to umiałam określić, co mi przeszkadza, a co pomaga. To pozwoliło lepiej znajdować się w sytuacjach dźwiękowych.

Jakie trudności w procesie rehabilitacji napotykała Pani po pierwszej operacji?
Wszystko wymagało czasu... oczekiwania. Ale nie biernego.

\section{A na czym polegają obecne trudności pod względem słuchowym?}

Czasem ucieka mi coś z wypowiedzi, gdy są burzliwe dyskusje. Nie rozumiem swobodnie, gdy rozmawiam przez telefon. Uciekają mi skecze w kabaretach, dialogi w dubbingach, dialogi, gdy jestem pasażerem $\mathrm{w}$ hałaśliwym samochodzie, a ja siedzę z tyłu. Ale to są jakieś elementy w całym układzie sytuacji, zdarzeń dźwiękowych.

\section{Dzięki implantowi osiągnęła Pani...}

Spokój, swobodę, rozwój. Naprawdę mam wiele powodów, by się cieszyć. Mogę pełniej uczestniczyć w różnych zadaniach, np. czy to w domu, czy w pracy, czy podróżując.

Gdyby miała Pani wpływ na podejście personelu medycznego i rehabilitacyjnego, co by Pani im powiedziała?

Miałam to szczęście, że trafiłam na osoby, które dobrze pokierowały procesem diagnostycznym, operacyjnym i po operacji - rehabilitacyjnym.

\section{Kiedy zdecydowała się Pani na drugi implant?}

Po ok. siedmiu latach od pierwszego.

\section{Na drugi implant zdecydowała się Pani, gdyż...}

Zaczęło mi brakować drugiego ucha. W pewnych sytuacjach poczułam, że jedna strona jest słabsza. Po wszczepieniu drugiego implantu uzyskałam jeszcze większe korzyści z rozumienia mowy, szczególnie w hałasie.

\section{Jak na to wszystko patrzy Pani z perspektywy czasu?}

Uważam, że podjęłam jedną z lepszych decyzji w swoim życiu. Jestem bardzo zadowolona. Otrzymałam pomoc i mogę powiedzieć, że choć nie jestem w 100\% „normą słuchową", to mam wiele. Teraz ja pomagam i żeby było zabawnie - słyszącym.

Jak Pani sądzi, czy osoba, która nie ma problemu ze słuchem, jest $\mathrm{w}$ stanie postawić się w Pani sytuacji?

Dla wielu osób jest to nie do pogodzenia, że można jednocześnie słyszeć i nie rozumieć. Nie mówimy tu o języku obcym, ale o rodzimym. A jednak można, w wyniku nieprawidłowego słyszenia. Odczuwałam to bardzo często, np. podczas słuchania wykładu nauczyciela. Były momenty, że słyszałam i rozumiałam całe zdania, pod warunkiem, że był zwrócony twarzą do klasy. Gdy się odwracał twarzą do tablicy, dalej tłumacząc zagadnienie i pisząc jakieś wzory lub pojęcia na niej, już brakowało rozumienia, co wypowiada. Głos był słyszalny, głośność wypowiedzi ta sama, odległość ta sama, ale rozmywało się to, co kryje się w przekazie. Tak samo, gdy koledzy i koleżanki zabierali głos $\mathrm{w}$ dyskusji, odpowiadali na pytania nauczyciela. Musiałam odwracać się zawsze w stronę tej osoby, która się wypowiadała, żeby cokolwiek wiedzieć. 
Dlaczego? Bo wystarczyło, że zabrakło dźwięków o wysokim zabarwieniu i całość przypominała bełkot. Gdy widziałam twarz, mogłam dopowiedzieć sobie $\mathrm{z}$ ruchu ust to, czego nie było już słychać. Czytanie lub doczytywanie $\mathrm{z}$ ust to taki sposób, który ułatwia funkcjonowanie osobie częściowo słyszącej lub niesłyszącej. Gdy dłużej korzystałam $\mathrm{z}$ implantu ślimakowego, zauważyłam, że zaczynam coraz mniej uwagi zwracać na usta, a coraz bardziej polegać na moim „elektrycznym słuchu”. Pewnego razu ktoś mi dyktował tekst, zaczęłam pisać na klawiaturze komputera. Nagle ta osoba przerwała mi i mówi: proszę, spójrz na mnie. Zdziwiona zapytałam: po co? Przecież nie wiesz, co powiedziałam. Ja odparłam, że wiem, bo usłyszałam, i przeczytałam ostatnie zdanie. Zdziwiła się. Pamiętała, że mogę nie rozumieć bez patrzenia na usta. Tak było wcześniej, ale z implantem rozumiałam, bo docierały do mnie brakujące dźwięki, dźwięki odpowiedzialne za różne głoski. Mogłam to zebrać w całość i zrozumieć. Takie i inne sytuacje związane ze słyszeniem bez implantu i z implantem można porównać do sceny w teatrze. Osoby, które wszystko słyszą (dźwięki niskie, średnie i wysokie w pełnej skali głośności - od cichych przez średnio ciche do głośnych), są jak widownia, która widzi całą panoramę sceny. Taka widownia zauważa wszystkie elementy scenografii, aktorów, efekty specjalne. Osoba, która częściowo słyszy, to jak widownia, która ma niepełny obraz na scenę, np. siedzi w przybocznym balkonie i widzi połowę sceny. Czasem może nie zdawać sobie sprawy, że w rogu sceny stoi aktor, bo tego z balkonu go nie widać. Dlatego każdy, kto ma pieniądze i odpowiednio wcześnie dowie się o sprzedaży biletów, kupuje miejsce na środku, bliżej sceny, żeby mieć jak najlepszy widok na sztukę. Nikt nie lubi być na skraju, z boku, za daleko. Wtedy uciekają różne rzeczy z przedstawienia i to już nie jest taka jakość i radość $\mathrm{z}$ obecności na przedstawieniu.

Gdyby mogła Pani wrócić do przeszłości i coś zmienić pod względem słuchowym, to co by Pani zrobiła...?

Szkoda, że nie mogłam mieć wcześniej implantu. Tylko wtedy jeszcze nie wszczepiano implantów osobom $z$ resztkami słuchowymi. No i zastanawiam się, czy byłabym dojrzała do takiej decyzji w szkole podstawowej lub w liceum? Nie wiem...

Co by Pani powiedziała osobie, która stoi przed wyborem: implant czy brak podjęcia ryzyka?

Jeśli taka osoba pozna i spojrzy na swoją sytuację szeroko, od strony medycznej, ale i swoich oczekiwań, i będzie umiała odróżnić możliwości urządzenia od możliwości swojego organizmu, zastanowić się, co osobiście dla niej może wyniknąć $\mathrm{z}$ tej decyzji, i będzie gotowa podjąć wyzwanie, pewne trudy przebycia procesu zmian... poradziłabym, by zawalczyła o siebie i spróbowała.

Czy chciałaby Pani jeszcze coś dodać istotnego, co nie zostało poruszone, a wydaje się być ważne na tę chwilę?

Wydaje mi się ważne, żeby nie uciekać przed wyzwaniami, ale próbować, tylko nie ślepo, lecz z namysłem, przygotowując się do ewentualnych zmian. Można wiele wygrać. To się wiąże także z decyzją dotyczącą wszczepienia implantu.
To bardzo ciekawe, co Pani powiedziała. Bardzo dziękuję za ten wywiad, „rzuca” on dla mnie nowe światło na sytuację osób z częściową głuchotą. Jestem niezmiernie wdzięczna i pełna podziwu za determinację, ale i za odwagę, gdyż tak naprawdę ludzie nie zastanawiają się nad tym, ile osoba $z$ dysfunkcją słuchu musi mieć siły i wręcz heroizmu, by funkcjonować na podobnym poziomie co inni i do tego pogodnie oraz $z$ dystansem patrzeć na to, co ją spotkało.

\section{Dyskusja}

\section{Analiza uzyskanego materiału}

Wywiad został przeprowadzony w ośrodku klinicznym, a przygotowany arkusz pytań był jedynie planem ramowym wywiadu, bowiem w czasie rozmowy i korespondencji pojawiały się nowe wątki warte uwagi i wymagające dostosowywania pytań na bieżąco. Rozmówczynię cechowała duża otwartość i swoboda mówienia, pozytywne nastawienie, by dzielić się swoim doświadczeniem dla dobra innych.

Przeprowadzony wywiad ukazuje doświadczenia życiowe pacjentki przed wszczepieniem i po wszczepieniu implantu w odniesieniu do konsekwencji niepełnosprawności. Jest to studium jednego przypadku i zarys zmieniającego się funkcjonowania pacjentki. Natomiast obraz ten nie jest pełny. Narzędzie to w swej formule wywiadu narracyjnego, mimo pewnego szkicu i planu ramowego rozmowy, jest formą podążania za osobą i otwierania się na kwestie rozwijane i poruszane przez pacjenta. Celowo nie ingeruje się zbytnio w swobodną wypowiedź, by uniknąć sugestii. Uzyskany w ten sposób materiał poddany zostaje analizie.

Pacjentka z tytułu swojej dysfunkcji doświadczyła konsekwencji zarówno biologicznych, które są punktem zainteresowania w medycznym modelu niepełnosprawności, konsekwencji psychicznych i społecznych, które można odnieść do funkcjonalnego modelu niepełnosprawności, jak i konsekwencji wynikających z relacji ze społeczeństwem, z nastawienia innych ludzi do osób niepełnosprawnych, do czego odnosi się społeczny model niepełnosprawności.

O doświadczaniu konsekwencji biologicznych świadczą zacytowane poniżej wypowiedzi. Opisują one problemy osób z częściową głuchotą, takie jak: • ograniczenie możliwości odbioru informacji dźwiękowej: „Głos był słyszalny, głośność wypowiedzi ta sama, odległość ta sama, ale rozmywało się to, co kryje się w przekazie”, „Osoba, która częściowo słyszy, to jak widownia, która ma niepełny obraz na scenę, np. siedzi w przybocznym balkonie i widzi połowę sceny. Czasem może nie zdawać sobie sprawy, że w rogu sceny stoi aktor, bo tego z balkonu nie widać"; - trudne do uświadomienia, bo stopniowe tracenie słuchu: „Radziłam sobie. Może dlatego, że niedosłuch nie nastąpił nagle, ale pogłębiał się bardzo małymi kroczkami”, ,ja sama dobrze nie zdawałam sobie z tego sprawy"; • brak korzyści z aparatów słuchowych (możliwość wzmocnienia jedynie czynnych i funkcjonalnych obszarów słuchu fizjologicznego): „Próbowałam nosić aparaty słuchowe, ale one nic nie wzmacniały, nie słyszałam w nich utraconych dźwięków” lub „Za każdym razem aparaty wzmacniały to, co dobrze słyszałam - było to nienaturalnie za głośno. Ale nie wspomagały tego, czego nie słyszałam. Okropne 
uczucie”; • przymus patrzenia na usta, by zrozumieć komunikat: „Pamiętała, że mogę nie rozumieć bez patrzenia na usta”, „Gdy widziałam twarz, mogłam dopowiedzieć sobie z ruchu ust to, czego nie było już słychać".

Po zastosowaniu interwencji medycznej sytuacja pacjentki zmieniła się pod względem konsekwencji biologicznych. Dzięki systemowi implantu ślimakowego pacjentka zaczęła odbierać wcześniej niesłyszane dźwięki: „...są dźwięki, o których nie miałam pojęcia, bo ich nigdy nie słyszałam, a teraz dochodzą do mnie”. W konsekwencji poprawiło się rozumienie komunikatów werbalnych: „Mogłam to zebrać w całość i zrozumieć”, bez przymusu śledzenia ruchu warg rozmówcy w toku rozmowy: „Gdy dłużej korzystałam $\mathrm{z}$ implantu ślimakowego, zauważyłam, że zaczynam coraz mniej uwagi zwracać na usta, a coraz bardziej polegać na moim „elektrycznym słuchu”. W momencie poprawy percepcji słuchowej na jedno ucho pacjentka zaczęła odczuwać dyskomfort w związku z brakiem odbioru dźwięku przez drugie ucho. To doprowadziło do podjęcia decyzji o wszczepieniu drugiego implantu i w konsekwencji do dalszej poprawy percepcji słuchowej: „Po wszczepieniu drugiego implantu zyskałam jeszcze większe korzyści $\mathrm{z}$ rozumienia mowy, szczególnie w hałasie”.

W świetle medycznego modelu niepełnosprawności oddziaływanie rehabilitacyjne i zastosowanie kompensacji poprzez protezę, jaką jest implant ślimakowy, poprawiło $\mathrm{u}$ pacjentki percepcję słuchową, rozumianą w literaturze jako funkcja ciała [14].

Przechodząc do konsekwencji wynikających z funkcjonalnego modelu niepełnosprawności, możemy przeanalizować obszar funkcjonowania psychicznego i społecznego. W zakresie konsekwencji psychicznych doświadczanych przez pacjentkę można mówić o przeżywaniu silnych emocji: „Byłam niepewna siebie, spięta”, będących wtórnie źródłem stresu i prowadzących do dużego obciążenia psychicznego: „a ja już byłam bardzo zmęczona ciągłym nadrabianiem różnymi sposobami w sytuacjach, kiedy coś mi uciekało lub mogło uciec. Musiałam ciągle przewidywać”. Miało to wpływ na postrzeganie obrazu samej siebie: „Nie myślałam, że mam kłopot ze słuchem, tylko z innymi sferami. Myślałam, że nie wyrabiam się jak inni, jestem powolna, „gapowata”, za bardzo zamyślona. Gdy zaczęłam łączyć to, co się dzieje, $\mathrm{z}$ niedosłuchem, to musiałam też siebie definiować na nowo - to jaka jestem". Nie wpłynęło to jednak na poczucie własnej wartości i pozytywne nastawienie do przezwyciężania trudności: „Ale miałam poczucie własnej wartości. Starałam się tym nie przejmować”.

Wszczepienie implantu ślimakowego w początkowej fazie procesu rehabilitacyjnego nie oznaczało końca zmagania się z silnymi emocjami, natomiast zmotywowało pacjentkę do konstruktywnego poradzenia sobie $\mathrm{z}$ doświadczanymi trudnościami: „Były momenty, że czułam się zdezorientowana, zaskoczona, zakłopotana, poirytowana, ale próbowałam skupiać się nie na tym, co mi sprawia trudność, ale co w ogóle do mnie dochodzi, otaczałam się dźwiękami i poddawałam ich stymulacji”. Zauważanie postępów przyczyniło się stopniowo do zwiększenia poczucia bezpieczeństwa pacjentki: „... zrozumiałam, że zaczyna się dla mnie stopniowo stabilizować słyszenie i rozumienie. Odczuwałam, że mogę coraz bardziej zaufać nowemu słyszeniu, poczuć się pewniej”. Sprawiło jej to wyraźną ulgę, gdyż odzyskała: „Spokój, swobodę...”. Pozytywne efekty implantacji pozwoliły również na przeformułowanie obrazu samej siebie i akceptację swojej niepełnosprawności: „Wzrosła moja samoświadomość, „zaczęłam rozumieć, czym jest mój niedosłuch... nauczyłam się mówić o niedosłuchu w sposób otwarty” i dały - w opinii pacjentki szansę na dalszy: „rozwój”.

Wątek, który się wielokrotnie pojawia w wypowiedziach pacjentki i stanowi pokaźną ich część, dotyczy konsekwencji społecznych, doświadczanych $\mathrm{z}$ racji niepełnosprawności, zawierających się również w funkcjonalnym modelu niepełnosprawności. Pacjentka zaznacza, że jej niedosłuch miał znaczący wpływ na kontakty społeczne i na sposób postrzegania przez innych jej osoby: „Mogło to bardziej wpływać na ich postrzeganie mojej osoby, np. wołają mnie, a ja nie reaguję albo odpowiadam nie na temat", jak i uczestnictwo w pewnych aktywnościach czy izolowanie się samej pacjentki: „Nie mogłam się dobrze odnaleźć w grupie”, „Nie wdawałam się w grupowe dyskusje na przerwie, nie łapałam żartów klasowych, zawsze gdy na lekcjach były dyskusje lub ktoś wypowiadał się, odwracałam się, by lepiej wychwycić, co mówi”. Nie ułatwiało to integracji społecznej, natomiast skłoniło ją do utrzymywania, w większej mierze, kontaktów indywidualnych: „Raczej nawiązywałam wiele indywidualnych kontaktów, jeden na jeden”. Niedosłuch wiązał się z ogromnym trudem wkładanym w osiągnięcie tego, co innym przychodziło z łatwością: „Ciągle coś uzupełniałam, robiłam notatki, więcej czytałam, żeby być na tym samym poziomie informacji co rówieśnicy”, „osiągałam wyniki w nauce nieodbiegające od średniej. Raz wypadałam bardzo dobrze, raz średnio. Nic, co niepokoi”, z uwzględnieniem większego nakładu czasu i energii: „To samo, gdy koledzy i koleżanki zabierali zdanie $\mathrm{w}$ dyskusji, odpowiadali na pytania nauczyciela. Musiałam odwracać się zawsze w stronę tej osoby, która się wypowiada...”, czy próbą odnalezienia się w zmieniających warunkach akustycznych, chociażby z uwagi na ilość osób: "Ale pamiętam, że trudno mi było rozmawiać w gwarze".

Po wszczepieniu implantu ślimakowego pacjentka uzyskała większą pewność siebie i - jak relacjonuje - swoich potrzeb, a także większą kontrolę nad swoją sytuacją: „Nauczyłam się mówić o niedosłuchu w sposób otwarty. Przez to umiałam określić, co mi przeszkadza, a co pomaga. To pozwoliło lepiej znajdować się w sytuacjach dźwiękowych”. Ma też większą motywację do działania: „Wszystko wymagało czasu...oczekiwania. Ale nie biernego". I mimo że funkcjonowanie pacjentki nie jest takie jak osoby niemającej problemów ze słuchem: „Czasem ucieka mi coś $\mathrm{z}$ wypowiedzi, gdy są burzliwe dyskusje. Nie rozumiem swobodnie, gdy rozmawiam przez telefon. Uciekają mi skecze w kabaretach, dialogi w dubbingach, dialogi, gdy jestem pasażerem w hałaśliwym samochodzie, a ja siedzę z tyłu...", to nie przejmuje się tym i traktuje to jak szczegół: „...Ale to są jakieś elementy w całym układzie sytuacji, zdarzeń dźwiękowych”. Pacjentka cieszy się, że zyskała sposobność do dalszego rozwoju, czy to na gruncie rodzinnym czy zawodowym, czy w trakcie realizacji swoich pasji: „Naprawdę mam wiele powodów, by się cieszyć. Mogę pełniej uczestniczyć w różnych zadaniach, np. czy to w domu, czy w pracy, czy podróżując”, „Teraz 
ja pomagam i żeby było zabawnie - słyszącym”. O subiektywnej poprawie jakości życia pacjentki mogą świadczyć również jej słowa: „Uważam, że podjęłam jedną z lepszych decyzji w swoim życiu.”

W odniesieniu do konsekwencji wynikających ze społecznego modelu niepełnosprawności pacjentka nie wspomina o jawnym negatywnym nastawieniu społeczeństwa do siebie $\mathrm{z}$ racji swojego niedosłuchu, szczególnie ze strony swojego najbliższego otoczenia: „Na moich bliskich raczej nie widziałam, żeby jakoś wpływał”. Natomiast pewne wypowiedzi wskazują, że pacjentka nie czuła do tej pory zrozumienia dla swojej sytuacji: „Gdy rozpoczęła się diagnostyka w kierunku implantu, zaczęłam otrzymywać informacje. Mogłam porozmawiać z lekarzami, którzy rozumieli moją sytuację i moje problemy. Pierwszy raz poczułam się zrozumiana" lub była traktowana w wyróżniający się sposób: „Miałam czasem wrażenie, że jestem $\mathrm{w}$ niektórych momentach postrzegana jako gapa albo „z uśmiechem”. Sporym utrudnieniem było również ograniczenie w realizowaniu roli, którą była dla pacjentki w tamtym czasie rola ucznia/studenta, spowodowane niezrozumieniem przez innych potrzeb osoby z częściową głuchotą: „Dla wielu osób jest nie do pogodzenia, że można jednocześnie słyszeć i nie rozumieć. (...) Odczuwałam to bardzo często, np. podczas słuchania wykładu nauczyciela. (...) Gdy się odwracał twarzą do tablicy, dalej tłumacząc zagadnienie i pisząc jakieś wzory lub pojęcia na niej, już brakło rozumienia, co wypowiada”.

Z wywiadu nie wynika, w jaki sposób zmieniło się nastawienie społeczeństwa po operacji i rehabilitacji pacjentki względem niej samej. Znajdujemy tu jedynie opinię pacjentki wobec środowiska medycznego i rehabilitacyjnego - rozumiejącego $\mathrm{z}$ racji swej profesji problem niedosłuchu: „Miałam to szczęście, że trafiłam na osoby, które dobrze pokierowały procesem diagnostycznym, operacyjnym i po operacji - rehabilitacyjnym". Należałoby bliżej przyjrzeć się temu obszarowi. Nie ma tu bowiem wzmianki ani o negatywnym, ani o pozytywnym nastawieniu społeczeństwa. Zacytowane już wcześniej słowa: „Teraz ja pomagam i żeby było zabawnie - słyszącym” mogą świadczyć o tym, że pacjentka została włączona w społeczeństwo, nie tylko jako biorca, lecz także jako dawca oddziaływań społecznych. Jednak nie jest to na tyle jednoznaczne, by sądzić, że to społeczeństwo zmieniło swoje nastawienie wobec osoby niepełnosprawnej, wykazując akceptację dla niedosłuchu, ale wskazuje raczej na to, że pacjentka, funkcjonując ,jak osoba pełnosprawna” dzięki korzyściom z implantów, wykazała gotowość do podjęcia aktywności społecznej. Co wcześniej, z uwagi na częściową głuchotę, nie było możliwe. W konsekwencji można powiedzieć, że pacjentka „uchroniła się” czy została ochroniona przed opresją ze strony społeczeństwa.

\section{Wnioski}

W pracy odwołano się do trzech modeli niepełnosprawności: medycznego, funkcjonalnego i społecznego, analizując zmiany w obrębie konsekwencji niepełnosprawności takich jak: konsekwencje biologiczne, psychiczne i społeczne, jak również konsekwencje w postaci opresji czy niezrozumienia społecznego.
Pacjentka nadal jest osobą niedosłyszącą, natomiast adekwatne zastosowanie protezy, jaką jest system implantu ślimakowego, pozwoliło na zmiany w jej życiu. Na podstawie tego wywiadu można wnioskować, że po wszczepieniu implantu ślimakowego życie pacjentki zmieniło się, bowiem konsekwencje niepełnosprawności uległy zmniejszeniu.

Zmiany dotyczą konsekwencji biologicznych. Dzięki zastosowaniu interwencji medycznej w postaci implantów ślimakowych znacznie poszerzył się zakres percypowanych dźwięków. Zmiany te obserwujemy również w odwołaniu do modelu funkcjonalnego. Bohaterka tego wywiadu wielokrotnie podkreśla, jaki wpływ miał niedosłuch na jej życie wewnętrzne i społeczne. Mówi o obciążeniu psychicznym związanym z koniecznością ciągłego domyślania się treści napływających komunikatów i potrzebą wypracowania innych, alternatywnych sposobów radzenia sobie $\mathrm{z}$ wymaganiami otoczenia. Wspomina o poczuciu bycia innym, mniej skutecznym w stosunku do osób ze środowiska, w jakim funkcjonowała. Istotną kwestią w relacji pacjentki jest zmiana, jaka zaszła w obrazie własnej osoby w momencie uświadomienia sobie, że konkretną przyczyną jej trudności jest niedosłuch. Zastosowanie metody implantu ślimakowego było punktem zwrotnym w życiu pacjentki. Nowe wrażenia słuchowe pozwoliły na wypracowanie efektywniejszej komunikacji $\mathrm{z}$ otoczeniem, co znacząco wzmocniło jej poczucie bezpieczeństwa w środowisku i poczucie własnej skuteczności w realizacji zadań stawianych przez otoczenie.

W opisywanej pracy model społeczny niepełnosprawności znalazł zastosowanie w najmniejszym stopniu, odpowiedzi pacjentki nie dotyczyły bowiem tej kwestii. Można by sądzić, iż wnikliwsze pytania w przeprowadzonym wywiadzie pozwoliłyby na uzyskanie większej ilości informacji na ten temat.

Jednym z celów tej pracy, poza ukazaniem na przykładzie wybranego przypadku zmian, które zaszły w życiu osoby z częściową głuchotą w świetle konsekwencji niepełnosprawności przed wszczepieniem i po wszczepieniu implantu, była próba dostrzeżenia obszarów jeszcze niepoznanych, wartych zainteresowania i badań.

Na przykładzie omawianego przypadku pacjentki z częściową głuchotą można zaobserwować zmiany, które zaszły w jej życiu po wszczepieniu implantu ślimakowego. Zatem warto by było to zagadnienie rozszerzyć o dalsze badania ilościowe, by otrzymać zasobniejszy materiał do analizy. Uzyskane wnioski nie są bowiem i nie mogą być podstawą do wyrobienia sobie jednoznacznej opinii na temat życia osób z częściową głuchotą i nie mogą być generalizowane. Kontynuacja badań nad zmianami w życiu osób z częściową głuchotą w świetle modelu funkcjonalnego wydaje się być szczególnie ciekawym zagadnieniem, gdyż według wiedzy autorki tej pracy obszar ten pozostaje nadal niezbadany.

\section{Podziękowania}

Dziękuję Kolegom i Koleżankom z Instytutu Fizjologii i Patologii Słuchu w Kajetanach za wkład w badania oraz uwagi merytoryczne podczas pracy nad manuskryptem. 


\section{Piśmiennictwo:}

1. Skarżyński H, Lorens A, Piotrowska A. A new method of partial deafness treatment. Med Sci Monit, 2003; 9(4): 20-4.

2. Skarżyński H, Lorens A, Piotrowska A, Anderson I. Partial deafness cochlear implantation provides benefit to a new population of individuals with hearing loss. Acta Otolaryngologica, 2006; 126(9): 934-40.

3. Skarżyński H, Lorens A, Piotrowska A, Anderson I. Partial deafness cochlear implantation in children. Int J Pediatr Otorhinolaryngol, 2007; 71(9): 1407-13.

4. Skarżyński H, Lorens A, Piotrowska A, Anderson I. Preservation of low frequency hearing in partial deafness cochlear implantation (PDCI) using the round window surgical approach. Acta Otolaryngologica, 2007; 127(1): 41-8.

5. Skarzynski H, Lorens A, Piotrowska A, Podskarbi-Fayette R. Results of partial deafness implantation using various electrode designs. Audiol Neurotol, 2009; 14(Suppl.1): 39-45.

6. Skarżyński H, Lorens A, Piotrowska A, Skarżyński PH. Hearing preservation in partial deafness treatment. Med Sci Monit, 2010; 16(11): 555-62.

7. Lorens A, Polak M, Piotrowska A, Skarżyński H. Outcomes of treatment of partial deafness with cochlear implantation: A DUET study. Laryngoscope, 2008; 118(2): 288-94.
8. Lorens A, Skarżyński H, Piotrowska A. New methods of deafness and partial deafness treatment. Biocybernetics and Biomedical Engineering, 2006; 26: 75-83.

9. Lorens A, Piotrowska A, Skarżyński H, Obrycka A. Zastosowanie elektronicznych protez wszczepialnych w leczeniu niedosłuchów. Pol Merkuriusz Lek, 2005; 19(111): 487-9.

10. Szczepankowski B. Niesłyszący-Głusi-Głuchoniemi. Wyrównanie szans. Warszawa: WSiP; 1999.

11. Rutkowska E. Rehabilitacja i pielęgnacja osób niepełnosprawnych. Lublin: Czelej; 2002.

12. Rzempowska J. Socjomedyczne aspekty funkcjonowania młodych osób niepełnosprawnych w środowisku wiejskim. Uniwersytet Medyczny im. Karola Marcinkowskiego w Poznaniu; 2011.

13. Brzezińska AI. Diagnoza potrzeb i modele pomocy dla osób z ograniczeniami sprawności. Warszawa: SCHOLAR; 2010.

14. Sęk H. Psychologia Kliniczna 2. Warszawa: PWN; 2005.

15. Pilch T, Bauman T. Zasady badań pedagogicznych. Strategie ilościowe i jakościowe. Warszawa: „Żak”; 2001.

16. Łobocki M. Metody badań pedagogicznych. Warszawa: PWN; 1982.

17. Śliwińska-Kowalska M. Audiofonologia Kliniczna. Łódź: Mediton; 2005.

18. Hojan E. Dopasowanie aparatów słuchowych. Poznań: Mediton; 2009. 